\title{
Deconstruction of the Concept of Former Convicts in the Law Number 10 Year of 2016 Concerning the Election of a Regional Head
}

\author{
Tongat \\ \{tongat@umm.ac.id\} \\ Universitas Muhammadiyah Malang, Indonesia
}

\begin{abstract}
This study was aimed at analyzing the concept of "former convict" in the Law Number 10 Year 2016 and the related laws causing public confusion. Ambiguous interpretations of who is qualified as a former convict result in long debates especially when it was approaching to the 2020 regional heads elections. Conceptual discussions of the matter become interesting issues in the regional head's elections. In some areas, the debates on the concept of former convicts may end in the courts. This present article will bring up the main issue of ambiguous interpretations of the concept of former convicts in the election of a regional head and the deconstruction of the construct in the Law Number 10 Year of 2016. Therefore, this writing is aimed at analyzing the ambiguous interpretations of the concept of former convicts and the efforts that may be made to deconstruct the concept. Through a normative study, the results of the analysis are as follows. First, the ambiguous interpretations of the meaning of former convicts arise due to inconsistency in using the legal term. As a result, to assure its legal certainty, the use of the legal term in various laws should be consistent in line with the applicable laws. Second, the deconstruction of the concept of former convicts should be adjusted to the prevailing regulations.
\end{abstract}

Keywords: Deconstruction, Former Convicts, Election, Regional Head

\section{Introduction}

It is indicated that the stipulation of Article 7 (2) explicitly states that the Candidates for Governor and Vice-governor, Regent and Vice-regent and also Mayor and Vice-mayor as mentioned in the verse (1) should fulfill the predetermined requirements. One of the requirements as stated in the Law Number 10 Year of 2016 as required in the stipulation of the Article 7 (2) letter $g$ is that one is never a convict on the basis of the decision made by the court with permanent legal force or for a former convict, one openly and sincerely tells the public that one is a former convict. The rationale of this stipulation is greatly various such as to prevent corruptions [1], to avoid corrupt leaders [2] and to assure the integrity of a leader [3].

The requirements in the election of the regional head are further stipulated in the Regulation of the General Elections Commission Number 1 Year of 2020 Regarding the candidacy for Governor and Vice-governor, Regent and Vice-regent, and/or Mayor or Vicemayor. In the stipulation of the Article 4 (1) of the Regulation of the General Elections Commission Number $1 / 20$, it is stated that Indonesian citizens may become candidates for Governor and Vice-governor, Regent and Vice-regent, or Mayor and Vice-mayor by fulfilling predetermined requirements. One of the requirements is as expressed in the stipulation of the 
Article 4 (1) letter $f$ of the Regulation of the General Elections Commission Number 1 Year of 2020, namely one is never a convict based on a court decision that has got a permanent legal force since one has committed a crime threatened with 5 (five) years or more in jail. The studies of the requirements of the candidacy in the election of a regional head has been done by Aryani and Hermanto [3], Amrullah [4] also by Hardiyanto et al. [5].

The stipulation of the Article 4 (1) letter $\mathrm{f}$ of the Regulation of the General Elections Commission Number 1 Year 2020 containing requirements of candidates in the election of a regional head is followed up by the emergence of the stipulation of the Article 4 (2a) Regulation of the General Elections Commission No. 1 Year of 2020 that explicitly states that one is never a convict as mentioned in the Article (1) letter f except for a former convict that has passed a period of 5 (five) years after completing the punishment in the prison based on the court decision that has permanent legal force. It is the stipulation of the Article 4 (2a) of the Regulation of the General Elections Commission Number 1 Year 2020 that then triggers prolonged pros and cons in the administration of the regional head's election.

\section{Research Method}

It is legal research with some approaches. They are statute, analytical, and philosophical approaches [6]. This research would start from a textual study namely the regulations and judge decisions. It would study legal norms contained in the regulatory texts (regulatory languages). However, it would not merely see legal languages as meanings from a static dimension but also as events or discourses possessing living and dynamic dimensions. As a result, this research would not only make interpretations of texts but also catch contextual meanings of texts/languages of the regulations [7]. It would also explore values in laws; therefore, it would be also philosophical research [8]. It would not only see a law in its textual appearance, but also in its ideas, ideals, values, morale's and justice called as a legal concept which is ideological, philosophical, and moralistic in nature [9]

\section{Results and Discussion}

\subsection{Ambiguous Interpretations of the Concept of a Former Convict in the Law No. 10 Year of 2016 Regarding Regional Heads Elections}

Referring to the stipulation of the Article 7 (2) letter $g$ of the Law Number 10 Year of 2016 regarding the Second Amendment of the Law Number. 1 Year of 2015 on the Determination of the Government Regulation in Lieu of Laws Number 1 Year of 2014 regarding the Elections of Governor, Regent, and Mayor into a law, it is clearly stated that the use of the term "former convict" in the context of the law is improper. Moreover, in the official explanation of the Article 7 (2) letter $g$ of the Law Number 10 year of 2016 it is clearly declared that what is meant by "former convict" is one that does not have any relation either technically (crime) or administratively to any ministers in the administration of government affairs in the legal field or human rights except former convicts of narcotics and drug dealers and the convicts in sexual crimes to children. The explanation of the Article 7 (2) letter g of the Law Number 10 Year of 2016 feels very odd, remembering that the status of a convict that will serve as a criminal period has been a "former convict (mantan terpidana)" or becomes a "convicted (narapidana)" and 
technically or administratively it is impossible to have any relations with the ministers in the administration of the government affairs in the legal field and human rights. It is in this place where the term "former convict" occurs in the context of the Article 7 (2) letter g of the Law Number 10 Year of 2016. All convicts that will serve their sentence in prison technically and administratively will have relationships with the ministers who administrate the government affairs in the legal field and human rights. Even, when one changes his/her status from a convict into a convicted, it is the earliest stage in the coaching process.

It seems that what is meant in the Article 7 (2) letter g of the Law Number 10 Year of 2016 is one who has completed his/her punishment in the correctional institution, and s/he is not called a "former convict (mantan terpidana)" but a "former convicted (mantan narapidana)". Because, in the Criminal Procedural Law and also in the Law Number 12 Year of 1995 on Correctional Institution, various juridical terms dealing with the criminal law enforcement are clearly distinguished. Each juridical term possesses different meanings. In the context of the criminal procedural law, various terms may simultaneously refer to a stage where the concerned person is at the stage of a criminal court process namely a suspect, a convict, and a convicted. Meanwhile, since the mechanism of a criminal justice after the judge decision (verdict) is continued into the correctional institution, the juridical term in the criminal procedure law is proceeded in the Law Number 12 Year of 1995 on Correctional Institution. At the stage in the institution, the coaching stage of a convicted is tightly implemented, starting from a stage of the orientation admission to that of the assimilation [10]. At the stage of assimilation, it is meant that the convicted may be accepted by the society [11].

In the stipulation of the Article 1 Number 14 of the Law Number 8 Year of 1981 on Criminal Law, it is declared that a suspect is one who is due to his/her act or condition, on the basis of the preliminary evidence, is predictable as the doer of a crime. Meanwhile in the stipulation of the Article 1 Number 15 of the Law Number 8 Year of 1981 on Criminal Law, a limitation is provided that a suspected is a suspect who is sued, examined, and tried in a court. whereas, according to the Article 1 Number 32 of the Law Number 8 Year of 1981 on the Criminal Law, a convicted is one who is convicted on the basis of a sentence that has obtained a permanent legal force. Therefore, it can be concluded that a suspect is someone who is in the investigation process, a suspected is someone who is sued, examined and tried in the process of the court proceedings. While a convict is one who has been sentenced by a judge based on a sentence that has possessed a permanent legal force (incrahct van gewijsde) [12].

After one is sentenced by a judge based on the conviction verdict that has possessed a permanent legal force, s/he will be sent to a correctional institution to serve her/his punishment in prison. In line with the stipulation of the Article 10 (1) of the Law Number 12 year of 1995 on Correctional Institution, a convict accepted in the Correctional Institution is obliged to be registered. Then in the stipulation of the Article 10 (2) it is stated that the registration as meant in the verse (1) changes the status of a convict into a convicted. The change of the legal status from a convict into a convicted certainly also changes the concerned person's rights. The stipulation of the Article 10 (2) of the Law Number 12 Year of 1995 Regarding Correctional Institutional actually has distinguished explicitly who is meant as a convict and a convicted. On the basis of the stipulation of the Article 10 (2) of the Law Number 12 Year of 1995 on Correctional Institution, when a convict is registered in a correctional institution to serve his/her punishment period, his/her status changes. It is an early stage in the coaching process [13]. His/her status is not a "convict" anymore, but a "convicted". In a formal juridical manner, a convict serving his/her punishment in the correctional institution may be called a "former convict" and s/he should be cleared from any stigma [10]. 
Although s/he does not have any status as a convict -- s/he may also be called as a "former convict" -- s/he has some technical (criminal) or administrative relations with the ministers administrating the government affairs in the legal field and human rights. Because, his/her status is a convict, namely someone who is serving a punishment in a correctional institution. As a result, the designation of the term "former convict" in the Article 7 (2) letter g of the Law Number 10 Year of 2016 Regarding Regional Heads Elections and also its designation of its derivative terms in the Regulation of General Election Commission Number 1 Year of 2020 Regarding Candidacy for Governor and Vice-governor, Regent and Vice-regent, and/or Mayor and Vice-mayor either in the Article 4 (1) letter f and Article 4(2a) is contradiction in terminist. The mention of the term "former convict" in various regulations regulate regional heads elections potentially confuses the people. The description of the ambiguity of the concept of former convict in the Law Number 10 year of 2016 on Local Heads Elections and some related laws is presented in Table 1:

Table 1. The Term Convict in Various Regulations

\begin{tabular}{|c|c|c|}
\hline \multirow{2}{*}{ No } & \multicolumn{2}{|r|}{ Various Regulations } \\
\hline & The Articles that Regulate & The Article Texts \\
\hline 1 & $\begin{array}{l}\text { Article } 7 \text { (2) letter } \mathrm{g} \text { Law } \\
\text { Number } 10 \text { Year of } 2016 .\end{array}$ & $\begin{array}{l}\text { One is never a convict on the basis of a court decision } \\
\text { with permanent legal force or a former convict who } \\
\text { has declared to the public openly and sincerely that } \\
\text { one is a former convict. }\end{array}$ \\
\hline 2 & $\begin{array}{l}\text { Article } 1 \text { Number } 14 \text { Law } \\
\text { Number } 14 \text { Year of } 1981 \\
\text { Regarding the Criminal Law } \\
\text { Book. }\end{array}$ & $\begin{array}{l}\text { A suspect is someone due to his act or condition, } \\
\text { based on the preliminary evidence is properly } \\
\text { suspected as a criminal. }\end{array}$ \\
\hline 3 & $\begin{array}{l}\text { Article } 1 \text { Number } 15 \text { Law } \\
\text { Number } 8 \text { year of } 1981 \\
\text { Regarding the Criminal Law } \\
\text { Book. }\end{array}$ & $\begin{array}{l}\text { A defendant is a suspect who is charged, examined } \\
\text { and put on trial in court. }\end{array}$ \\
\hline 4 & $\begin{array}{l}\text { Article } 1 \text { Number } 32 \text { Law } \\
\text { Number } 8 \text { year of } 1981 \\
\text { Regarding the Criminal Law } \\
\text { Book. }\end{array}$ & $\begin{array}{l}\text { A convict is someone who has convicted based on a } \\
\text { court decision that has obtained permanent legal } \\
\text { force. }\end{array}$ \\
\hline 5 & $\begin{array}{l}\text { Article } 4 \text { (1) letter } f \text { of the } \\
\text { Regulation of the General } \\
\text { Election Commission Number } \\
1 \text { Year } 2020 \text { on Nomination of } \\
\text { the Election of governor and } \\
\text { vice-governor, regent and } \\
\text { vice-regent, and/or mayor and } \\
\text { vice mayor. }\end{array}$ & $\begin{array}{l}\text { One is never a convict based on the court decision that } \\
\text { has obtained permanent legal force because one has } \\
\text { committed a crime which is charged with } \\
\text { imprisonment } 5 \text { years or more, except the convict } \\
\text { who has conducted a crime due to negligence or a } \\
\text { political crime in the sense that an act stated as a } \\
\text { crime in the positive law only because the doer has } \\
\text { different political views with the ruling regime. }\end{array}$ \\
\hline 6 & $\begin{array}{l}\text { Article } 4(2 \mathrm{a}) \text { The Regulation } \\
\text { of the General Election } \\
\text { Commission Number } 1 \text { Year } \\
2020 \text { on the Nomination of the } \\
\text { Election of governor and vice- } \\
\text { governor, regent and vice- }\end{array}$ & $\begin{array}{l}\text { A requirement someone who is never as a convict as } \\
\text { stated in the article (1) letter f is excluded for a former } \\
\text { convict who is charged with imprisonment for } 5 \text { years } \\
\text { after completing punishment in prison based on the } \\
\text { court decision that has permanent legal force. }\end{array}$ \\
\hline
\end{tabular}




\begin{tabular}{|c|c|c|}
\hline & $\begin{array}{l}\text { regent, and/or mayor and vice } \\
\text { mayor }\end{array}$ & \\
\hline 7 & $\begin{array}{l}\text { Article } 10 \text { (1) Law Number } 12 \\
\text { Rear of } 1995 \text { on Correctional } \\
\text { Institution }\end{array}$ & $\begin{array}{l}\text { The convict accepted in the Correctional Institution } \\
\text { should be registered. }\end{array}$ \\
\hline 8 & $\begin{array}{l}\text { Article } 10(2) \text { Law Number } 12 \\
\text { Tahun } 1995 \text { on Correctional } \\
\text { Institution }\end{array}$ & $\begin{array}{l}\text { The registration as meant in the article (1) changes the } \\
\text { status of a convict into a convicted. }\end{array}$ \\
\hline
\end{tabular}

\subsection{Deconstructing the Concept of "Former Convict" in the Law Number 10 Year of 2016 Regarding the Election of a Regional Head}

Conceptually, the term deconstruction essentially is a term used to explain a next chapter of philosophy, an intellectual strategy or a model of understanding [14]. Referring to this general conception. In this writing, the term deconstruction means a way of explaining or of understanding or interpreting a legal text [15]. However, deconstruction basically is the way of interpreting a text by revealing hidden meanings, meanings behind the legal text itself. Therefore, the way of reading and interpreting is not linear, rigid, stiff and legalistic that often merely functions as a mirror producing the meaning that should be the same with its textual (literal) sound without paying attention to whether the produced meanings are in line with the reality or not, in accordance with the demands of the times or not, even they are in line with the justice or not [15].

The ambiguity of the concept "former convict" as stated above gets more chronic when it is related to the phrase of the next sentence in the stipulation of the Article 4 [2] of the Regulation of the General Elections Commission Number 1 Year of 2020, namely the phrase "that has passed a period of five years after completing punishment in prison based on the court decision that has permanent legal force". The ambiguity of the interpretation of the concept "former convict" not only confuse the people in general, but also the law enforcers themselves. This may be seen from the existence of interpretation growing among the law enforcers themselves dealing with the meaning of "former convict". A researcher of Perludem, Fadli Ramadhanil noted that at least there were two regions where former convicted participated in the 2020 Regional General Election had passed the process of the nomination disputes at the level of the local General Election Supervisory Agency (Bawaslu), namely Lampung Seladan and Dompu regencies [16]. In Lampung Selatan for example, the decision made by the local Bawaslu stipulated that a former convict is not categorized as someone who shall undergo a waiting period of 5 years. The argument given by the Bawaslu of Lampung Selatan was that the waiting period had started since the court decision had permanent legal force, and because the concerned person did not serve a sentence in the form of body confinement [16]. Meanwhile in the decision made by the Bawaslu in Dompu regency, in its legal consideration it was stated that the waiting period had started when a convict had left from a correctional institution [16]. Even the phrase "former convict" is often confused with the phrase "former convicted". Even though juridically, the term "convict" is different from the term "convicted". To give an overview of the meaning of "former convict", and the phrase "that has passed a period of five years after completing punishment in prison based on the court decision that has permanent legal force", the following analysis is presented.

Firstly, factually, the textual writing in the Article 4 (2a) of the General Elections Commission Number 1 Year of 2020 may be related to the stipulation of the Article 12 Year of 1995 on Correctional Institution. If it is linked with the stipulation of the Article 1 letter 7 of the 
Law Number 12 Year of 1995 on Correctional Institution, the phrase "passing a period of 5 (five) years after completing punishment in prison as stated in the Article 4 (2a) of the General Elections Commission Number 1 Year of 2020 may be interpreted as passing a period of 5 (five) years after the convict does not serve punishment in prison anymore. Remembering the textual 1 (implicit) stipulation of the Article 1 letter 7 of the Law Number 12 Year of 1995 on Correctional Institution, a limitation is clearly shown that a convicted is a convict that has committed a crime loss his independence in the correctional institution. Therefore, textually, a convicted that has not served his punishment prison is not called a convicted anymore, but $\mathrm{s} / \mathrm{he}$ may be qualified as a former convicted. The explanation of the limitation on a convicted as explicitly formulated in the stipulation of the Article 1 letter 7 of the Law Number 12 year of 1995 on Correctional Institution should be used as a binding reference, but not all convict sentenced may be called a convicted, for instance, a person who is sentenced a conditional punishment or probation. On the basis of this legal foundation, it is logical if one who is not in prison is not called a convicted anymore, but as a 'former convicted'. Hence, it can be understood that in the Letter of the Young Head of the Criminal Affairs of the Supreme Court of the Republic of Indonesia Number 30/Tuaka.Pid/IX/2015, especially in the third point, it is stated that someone with a conditionally free status since one has served his/her punishment the prison, is categorized as a former convicted. This foundation or way of thinking is based on grammatical or systematical interpretations.

Secondly, factually, the textual writing of the Article 4 (2a) of the Regulation of the General Elections Commission Number 1 Year of 2020 may also be linked with the stipulation of the Article 6 of the Law Number 12 Year of 1995 on Correctional Institution. When it is related to the stipulation of the Article 6 of the Law Number 12 Year of 1995 on Correctional Institution, the phrase "passing a period of 5 (five) years after serving punishment prison in the Article 4 (2a) of the Regulation of the General Elections Commissions Number 1 Year of 2020 may be interpreted as the pass of the period of 5 (five) years since the convicted has served his/her punishment in prison as decided by the judge. The textual (explicit) stipulation of the Article 6 of the Law Number 12 year of 1995 on Correctional Institution implies that the coaching of the inmates in prison is done in the correctional institution and their mentoring is in ' the Correctional Center. This stipulation implies that the process where a convict is serving his punishment in prison is also conducted by the Correctional Centre besides coaching by the Correctional Institution. The stipulation of the Article 6 of the Law Number 12 Year of 1995 regarding Correctional Institution implies that the coaching of a "convicted that has obtained conditional freedom" in the Correctional Center is one unity of coaching in the integrated criminal justice system [17].

Therefore, getting guidance in the Correctional Center may be included into serving the punishment. period. In the same vein, passing a period of 5 (five) years in the prison is interpreted as the passing of a period of 5 (five) years after completing punishment in prison as a whole (purely free). Hence, it can be understood that the Article 1 letter 21 of the Regulation of the General Elections Commission of the Republic of Indonesia Number 1 Year of 2000 on the candidacy for Governor and Vice-governor, Regent and Vice-regent, and/or Mayor and Vice-mayor states that a former convict is someone who has completed his punishment in prison, and technically (criminally) and administratively it is not related to the ministers that organize government affairs in the legal field and human rights. The construction of the Article 1 letter 21 of the Regulation of the General Elections Commission Number 1 Year of 2020 is actually from the official explanation of the Article 51 (2) letter $g$ of the Law Number 10 Year of 2016 that explicitly states that what is meant by "former convict" is someone who has not 
have any administrative or technical (criminal) relation with the minister organizing government affairs in the legal field and human rights.

Due to the wide and open interpretations of the term "former convict" in the Article 7 verse (2) letter $\mathrm{g}$ of the Law Number 10 Year of 2016 which is then followed by various regulations, the easiest way to do is to revise the stipulation of the Article 7 verse (2) letter $\mathrm{g}$ of the Law Number 10 Year of 2016. This revision is conducted at least to avoid two ambiguities.

\section{Conclusion}

On the basis of the short analysis above, some conclusions may be drawn: First is that the ambiguity of the interpretation of the concept "former convict" in the Law Number 10 Year of 2016 is caused by inconsistency in the use of the legal term which is not in line with the prevailing regulations. Therefore, to assure legal certainty, it is necessary to quickly revise the term in accordance with the current criminal procedure law. Second is that, deconstructing the concept "former convict" in the Law Number 10 Year of 2016 is multi-interpretative in nature, so that it potentially causes confusions among the people and some legal uncertainty.

\section{Acknowledgments}

I gratefully acknowledge that the research was financially supported by University of Muhammadiyah Malang, Indonesia.

\section{References}

[1] D. Fariz, "Pembatasan Hak Bagi Mantan Terpidana Korupsi Menjadi Calon Kepala Daerah,” J. Konstitusi, vol. 17, no. 2, pp. 309-329, 2020.

[2] W. Anjari, "Pencabutan Hak Politik Terpidana Korupsi dalam Perspektif Hak Asasi Manusia," J. Yudisial, vol. 8, no. 1, pp. 23-44, 2015.

[3] N. M. Aryani and B. Hermanto, "Justifikasi Hak Politik Mantan Narapidana: Perspektif Hak Asasi Manusia dan Perundang-Undangan,” J. Konstitusi, vol. 17, no. 2, pp. 413-436, 2020.

[4] M. S. Amrullah, "Pencabutan Hak Memilih Dan Dipilih Dalam Jabatan Publik Terhadap Narapidana Tindak Pidana Korupsi," J. Huk. Volkgeist, vol. 1, no. 2, pp. 164-176, 2017.

[5] M. L. Hardiyanto, S. S. Bagus, and A. Munir, "Hak Politik Mantan Narapidana Untuk Mencalonkan Diri Sebagai Calon Kepala Daerah (Analisis terhadap Putusan MK. No. 42/PUUXIII/2015)," Mimb. Yustitia, vol. 1, no. 2, pp. 106-122, 2017.

[6] J. Ibrahim, "Teori \& Metodologi Penelitian Hukum Normatif, cet III, Malang." bayumedia publishing, 2005.

[7] E. Warassih, "Penelitian Socio-Legal: Dinamika Sejarah Dan Perkembangannya," in Makalah Workshop, Forum Kajian Dinamika Hukum dan Majalah Ombudsman, Bandung, 2006.

[8] T. P. K. H. Yusriadi, Tebaran Pemikiran Kritis Hukum dan Masyarakat. Malang: Surya Pena Gemilang Publishing, 2009.

[9] R. H. Soemitro, "Perspektif Sosial dalam Pemahaman Masalah-Masalah Hukum," Semarang CV Agung, p. 1, 1989.

[10] P. N. Utami and H. Indonesia, "Keadilan Bagi Narapidana di Lembaga Pemasyarakatan,” J. Penelit. Huk. e-ISSN, vol. 2579, p. 8561, 2017.

[11] I. Rumadan, "Problem Lembaga Pemasyarakatan di Indonesia dan Reorientasi Tujuan Pemidanaan," J. Huk. dan Peradil., vol. 2, no. 2, pp. 263-276, 2013.

[12] S. Andi and A. Asis, "Hukum Acara Pidana Suatu Pengantar," Kencana, Jakarta, 2014.

[13] H. Dwiatmodjo, "Pelaksanaan pidana dan pembinaan narapidana tindak pidana narkotika (Studi 
terhadap Pembinaan Narapidana di Lembaga Pemasyarakatan Narkotika Klas IIA Yogyakarta)," Perspektif, vol. 18, no. 2, pp. 64-73, 2013.

[14] A. F. Susanto, Dekonstruksi Hukum Eksplorasi Teks dan Model Pembacaan, vol. 1. Genta Publishing, 2010.

[15] A. F. Susanto, Ilmu Hukum Non Sistematik (Fondasi Filsafat Pengembangan Ilmu Hukum Indonesia). LoGoz Publishing, 2015.

[16] Perludem, "Perludem: Ada 2 Mantan Napi Lolos Nyalon Pilkada 2020," Perludem, 2020. [Online]. Available: http://perludem.org/2020/10/26/perludem-ada-2-mantan-napi-lolos-nyalonpilkada-2020.

[17] T. A. Nugroho and J. Kavling, "Analisa Kebutuhan Pembimbing Kemasyarakatan Balai Pemasyarakatan (BAPAS) Bandung,” J. Ilm. Kebijak. Huk., vol. 13, no. 1, pp. 69-84, 2019. 